WIDER Working Paper 2016/95

\title{
Capital flight and development
}

An overview of concepts, methods, and data sources

Niels Johannesen ${ }^{1}$ and Jukka Pirttilä ${ }^{2}$

August 2016 
Abstract: This paper offers a critical review of the methods used to estimate the extent of capital flight and illicit financial flows from developing countries. The largest estimates in the literature are based on imperfect methods with a great margin for error. Emerging new studies have built on approaches that successfully isolate missing capital flows and wealth and attempt to address the causal impact of tax rates on capital flows. The results from these studies indicate that the extent of capital flight from developing countries, while smaller than in earlier estimates, is still a cause for concern.

Keywords: capital flight, illicit financial flows, taxation, developing countries JEL classification: $\mathrm{H} 26$, O10

Acknowledgements: We would like to thank Tony Addison, Konstantin Makrelov, and Finn Tarp for their helpful comments.

\footnotetext{
${ }^{1}$ University of Copenhagen, Denmark; ${ }^{2}$ University of Tampere, Finland and UNU-WIDER, Helsinki, Finland, corresponding author: jukka@wider.unu.edu

This study has been prepared within the UNU-WIDER project on 'The Economics and Politics of Taxation and Social Protection'

Copyright (C) UNU-WIDER 2016

Information and requests: publications@wider.unu.edu

ISSN 1798-7237 ISBN 978-92-9256-138-3
}

Typescript prepared by Lesley Ellen.

The United Nations University World Institute for Development Economics Research provides economic analysis and policy advice with the aim of promoting sustainable and equitable development. The Institute began operations in 1985 in Helsinki, Finland, as the first research and training centre of the United Nations University. Today it is a unique blend of think tank, research institute, and UN agency_providing a range of services from policy advice to governments as well as freely available original research.

The Institute is funded through income from an endowment fund with additional contributions to its work programme from Denmark, Finland, Sweden, and the United Kingdom.

Katajanokanlaituri 6 B, 00160 Helsinki, Finland

The views expressed in this paper are those of the author(s), and do not necessarily reflect the views of the Institute or the United Nations University, nor the programme/project donors. 
Capital flight features prominently in contemporary debates about economic development. In developing countries, capital is relatively scarce and the flight of assets which could have been employed productively in the domestic economy, is potentially extremely detrimental to development. This is notably the case if, as is often asserted, the capital exports by the economic elites dwarf capital inflows in the form of development aid and if the capital invested abroad remains outside the scope of domestic tax enforcement (e.g. Johannesen and Zucman 2014).

While capital flight is important from a theoretical perspective, empirical analysis is made difficult by the often furtive nature of cross-border capital flows by households. The literature has developed a number of methodologies aiming to measure capital flight, all of which build on important insights, but also have serious drawbacks and weaknesses. Given the importance of capital flight for economic development, it is important that measurement techniques are improved in order for us to gain a deeper understanding of its determinants and consequences.

This paper prepares the ground for this work by providing an overview of the empirical concepts, methods, and data sources developed and employed in the existing literature. We cover classical techniques such as 'sources-and-uses' as well as recent methodological contributions. We cover methods designed to capture capital flight by private households as well as those aiming to measure capital flight through firm trade. Our primary focus is measurement of capital flight, but we also briefly discuss empirical results pertaining to its underlying causes. Finally, we hope to inspire future research by pointing to a couple of novel data sources that may be useful in shedding light on capital flight. ${ }^{1}$

It can be helpful to provide a review of key concepts early on. There are many different definitions of capital flight. A broad notion is simply an outflow of money or securities, which is often related to sudden adverse economic conditions. All capital flight need not be illegal. The part which is, can be coined illicit financial (out)flows. The source of money for such flows can be illegal or the money is transferred in an illegal way, e.g. by avoiding taxes. Capital flight can occur due to action by individuals or within firms via tax-motivated shifting of paper profits. Firms can also be engaged in trade misinvoicing to transfer money across borders in a nontransparent, if not outright illegal way.

Given that we are dealing with an issue for which direct measures are not available, it is not surprising that many of the methods used in the existing literature are quite imperfect. For this reason, the results from some of the methods used prominently for measuring capital flight should be interpreted more cautiously than has often happened. If this is not done, monetary flows that are not really flight capital can be misleadingly classified as such. However, key recent studies have built on better data and more reliable methodologies. The results from such analysis confirm that the matter is relevant, although the magnitude of the flows appears smaller than earlier studies have suggested.

The paper proceeds in the following way. Section 2 covers measurement of capital flight based on macroeconomic identities, which is often most closely related to actions by private households. Section 3 covers those capital flight studies that use firm-level data or are otherwise

\footnotetext{
${ }^{1}$ Forstater (2015) offers a review of tax avoidance by multinational enterprises and its implications for developing countries. She points out that the potential of lost tax revenues falls below aid finance in poorest countries, since the bulk of the missing funds originate from middle income countries.
} 
more directly linked with the activities by the enterprise sector and by firms in the form of transfer mispricing. Section 4 discusses new data sources. Section 5 presents a comparison of the magnitude of the estimates of capital flight. Section 6 concludes. $^{2}$

\section{Estimates based on macroeconomic identities}

\subsection{Sources-and-uses method}

A common approach to estimating capital flight is the so-called sources-and-uses' method. The method makes inference about capital flight based on balance-of-payments statistics. If the sources of capital inflows, that is (net) increases in foreign debt and (net) increases in foreign direct investment (FDI), exceed the uses of capital inflows, that is the deficit on the current account and increases in the country's foreign reserves, this must be due to transfers of capital to foreign countries by private individuals. This residual is therefore a measure of capital flight.

\section{Box 1: Using balance of payments data to estimate capital flight}

This box introduces very briefly the logic of the sources-and-uses method and the hot-money-narrow method for estimating the extent of capital flight, based on Claessens and Naudé (1993). The methods use balance of payments in the following way.

A country's balance of payments identity implies that the following must be true

$-\mathrm{CA}=\mathrm{FDI}+\mathrm{STC}+\mathrm{PI}+\mathrm{BA}+\mathrm{CPR}+\mathrm{NEO}+\mathrm{LTC}$

Where

$\mathrm{CA}=$ current account, FDI $=$ foreign direct investment, $\mathrm{STC}=$ short-term capital flows, $\mathrm{PI}=$ portfolio investment, $\mathrm{BA}=$ deposit banks' foreign asset change, $\mathrm{CPR}=$ change in central bank foreign reserves, $\mathrm{NEO}=$ net errors and omissions, and LTC = long-term capital flows of the government sector.

The identity in (1) implies that if there is a current account deficit (meaning that -CA is positive), it needs to be financed by the items at the right-hand side.

Rewriting the identity gives

$-(\mathrm{LTC}+\mathrm{FDI}+\mathrm{CA}+\mathrm{CPR})=\mathrm{STC}+\mathrm{PI}+\mathrm{BA}+\mathrm{NEO}$

On the left, if sources (LTC + FDI) exceed uses of capital (CA + CPR), this is due to capital flight. Because of the balance of payments identity, capital flight can also be measured using the right-hand side of (2). It is clear from this that this notion of capital flight includes many legitimate investments, captured by PI and BA, maybe also STC.

The hot-money-narrow measure, therefore, takes into account only NEO (net errors and omissions) and, in some variants, also STC (short-term capital). At least the former arguably reflects more closely solely illicit flows, although, as the name says, it can also be a statistical error.

The method is employed widely both by international organizations like the World Bank and the United Nations (e.g. Claessens and Naudé 1993; UNDP 2011), non-governmental organizations (NGOs) like the Tax Justice Network (e.g. Henry 2012) as well as academic studies (e.g. Pastor 1990; Boyce 1992; Lensink et al. 2000). It has been used both to gauge the magnitudes of capital flight as well as to identify its economic and political determinants.

\footnotetext{
2 This paper does not really focus on the broader consequences of tax havens, apart from their role as facilitating (part of) capital flight. It is clear that tax havens also have other problematic features, such as enabling criminal activities by providing secrecy (Schjelderup 2016).
} 
A number of conceptual issues should be emphasized.

First, this measure of capital flight encompasses both legitimate and illegitimate capital transfers. For instance, to the extent that private households acquire foreign securities due to a portfolio diversification motive, such transactions will enter the measure of capital flight. This can be perceived both as a strength and a weakness. On the one hand, any sharp distinction between legitimate and illegitimate capital exports would be based on partly arbitrary criteria; it is conceptually cleaner to avoid such distinction by treating both as part of the same comprehensive phenomenon. On the other hand, completely open and legitimate money transfers to foreign countries motivated by a desire to diversify a portfolio of shares does not resonate well with most people's understanding of the notion of capital flight.

Second, the sources-and-uses approach provides a net measure of capital flight in the sense that inward and outward capital movements of equal magnitude neutralize each other and result in zero measured capital flight. This is a useful property for many purposes: if the stock of capital available for investment in a given country is what matters for economic development, then we should not be concerned about capital outflows if they are mirrored by capital inflows of equal magnitude. However, it also raises some conceptual issues. It implies, for instance, that measured capital flight can be negative, which is not really meaningful.

Third, it should be noted that because capital flight is determined residually as the difference between sources-and-uses of capital inflows, it will tend to compound the measurement error associated with these flows. If, for instance, the current account deficit is underestimated, this will cause capital flight to be over-estimated. If the flow of FDI is also underestimated, the two measurement errors will tend to cancel out, but if it is instead over-estimated, the two errors are compounded and capital flight will tend to be seriously over-estimated.

Applications of the sources-and-uses method yield estimates of annual capital flight from the least developed countries of around US $\$ 20$ billion (UNDP 2011) and from all developing countries of around US\$150-200 billion (Henry 2012).

Further, Henry (2012) uses the annual flow estimates of capital flight from developing countries to develop a stock estimate. Based on assumptions about the share of capital that is repatriated from offshore accounts and the average annual return to offshore capital, his 'accumulated offshore wealth model' sets the stock of accumulated capital belonging to developing countries at US\$7-9 trillion.

The literature has used the estimates of capital flight to analyse its underlying determinants. There is evidence that capital flight is driven by inflation and the risk of currency devaluation (Pastor 1990), foreign capital inflows in the form of borrowing (Boyce 1992; Ndikumana et al. 2014) and political risk (Lensink et al. 2000).

\subsection{Zucman method}

In a remarkable study, Zucman $(2013)^{3}$ used the differences in the assets and liabilities of all countries in the world to estimate the extent of missing wealth owned by individuals. The idea is that each country reports its international portfolio holdings. The destinations of investment are reported by countries as their liabilities. The asset ownership is registered using the residence

\footnotetext{
${ }^{3}$ In contrast to most other estimates of capital flight by individuals, Zucman's (2013) paper is published in a highly ranked peer-reviewed academic journal. The estimates were updated and further discussed in Zucman (2015).
} 
principle: France, for example, reports the foreign assets held by French citizens in French banks. However, French citizens can also hold assets in a foreign, offshore bank, for example in a tax haven. Tax havens do not typically report the assets owned by people not domiciled there. What this means is that it is likely that part of the assets held worldwide are unrecorded. A gap appears between total liabilities and total assets. Some liabilities appear to have no owners in official statistics, whereas in reality these securities are handled via tax havens.

The example of Switzerland illustrates the potential scale of the issue. Unlike most other tax havens, Switzerland in fact reports assets held by foreigners that are invested further via Swiss banks. The total wealth managed by Swiss banks that belonged to foreigners amounted to US $\$ 2.3$ trillion in 2015 . Forty per cent of the wealth is placed in mutual funds, in particular in funds domiciled in Luxembourg. The destinations of the rest of the wealth are mainly direct investments into global equities and bonds. The main challenge is that 60 per cent of the assets owned by foreigners are attributed to tax havens, such as the Virgin Islands and Panama, and the ultimate owners of these funds are not disclosed by the tax havens. Zucman proposes a rough method to overcome this problem: he assigns the funds belonging to foreigners in Swiss banks that are channelled via tax havens to actual origin countries to have the same proportional distribution as direct investments of foreigners into Swiss banks. This method suggests that the large proportion of assets owned by foreigners actually comes from Europeans (US $\$ 1.3$ trillion out of a total US $\$ 2.3$ trillion). This is understandable given the geographic location of Switzerland in the middle of Europe.

When estimating the extent of offshore wealth at a global scale, Zucman used as his base information from Lane and Milesi-Ferretti (2007), which has data for most countries in the world. He extends the data by including reserves held by central banks and data relating to the Cayman Islands. There are some other challenges, including the facts that China does not report the asset composition (bonds/equities) to the IMF and that data on oil exporters' holdings are not available. Zucman needs to make some assumptions regarding these missing items, which also means that the estimates he derives are just that: not a final word, but a good estimate. ${ }^{4}$

The outcome is that in 2008 , all foreign liabilities amounted to US $\$ 40$ trillion, whereas the total value of assets stood at US\$35.5 trillion. Thus, the gap was US $\$ 4.5$ trillion dollars. In the same year, the total value of wealth of individuals was US\$74 trillion (Davies et al. 2011), and therefore the missing wealth represents 6 per cent of the total wealth. The total wealth held in tax havens is somewhat larger, around 8 per cent. With updated estimates available in Zucman (2015), the amount of wealth held in tax havens was US\$7.6 trillion in 2014.

Why is it likely that the gap is indeed due to missing wealth and not to other issues, such as measurement errors? The reason is that the pattern in the missing wealth is consistent with the tax haven/tax evasion argument. Zucman infers this by using bilateral (investments from one country to another) data from the IMF's Coordinated Portfolio Investment Survey. The coverage of the survey is fairly good, but again the author needs to make some assumptions regarding the holdings of certain countries (China, oil exporters, Cayman Islands). With these caveats in mind, the results show that the extent of missing assets holdings is minimal for most (non-tax haven) countries, whereas the gap is the largest for key tax haven countries, including Luxembourg, Cayman Islands, and Ireland. Therefore, the missing assets are not randomly allocated but follow a certain pattern which is consistent with the view that the bulk of the missing wealth is indeed domiciled in tax havens.

\footnotetext{
${ }^{4}$ The estimate only includes financial wealth and therefore assets invested in real estate and luxury items, such as yachts, are not covered.
} 
Assuming a rate of return of 5 per cent for the undeclared wealth, applying an average tax rate on investment income, and also taking into account evaded inheritance and wealth taxes, the total annual tax revenue lost due to undeclared income held in tax havens is around US $\$ 190$ billion.

While in terms of absolute amount, the bulk of the missing wealth originates from rich countries, according to Zucman (2015, Table 1); the relative importance is the greatest for some developing areas. The missing wealth originating from Africa is US $\$ 500$ billion, representing 30 per cent of financial wealth. The same figures for Asia and Latin America are US\$1.3 trillion (4 per cent) and US $\$ 700$ billion (22 per cent). The implied tax revenue losses are US $\$ 14$, US $\$ 34$, and US $\$ 21$ billion dollars for Africa, Asia, and Latin America, respectively.

An interesting implication of Zucman's calculations is that the rich countries in the world, in particular the United States (US) and European countries, are probably net creditors rather than debtors (as the official statistics would suggest).

\subsection{Other approaches}

Several other approaches have been used to measure capital flight.

First, the 'hot-money-narrow' method (see Box 1 for more details), just like the sources-and-uses approach, measures capital flight while taking the balance of payments as a point of departure. One variant of this method includes only net errors and omissions in the measure of capital flight. Arguably, this represents capital flight that goes completely unrecorded in the capital account statistics and is therefore more likely to be illicit. Another variant also includes shortterm foreign portfolio investments by the household sector. Their short-term nature suggests that they may be induced by sudden changes in the political or economic environment. The method is applied in several academic studies of capital flight (e.g. Lensink et al. 2000) as well as by NGOs (e.g. Global Financial Integrity 2015). Recent estimates based on the hot-moneynarrow' method show capital flight from developing countries to be around US $\$ 200$ billion annually (Global Financial Integrity 2015). ${ }^{5}$

Second, Andersen et al (2016) take a different approach and use confidential data on crossborder bank deposits from the Locational Banking Statistics of the Bank for International Settlements to measure hidden wealth. They study how windfall gains from the resource sector translate into changes in balances on offshore bank accounts and argue that this reflects rent seeking by political elites and capital flight. They conclude that around 20 per cent of the resource rents accruing to countries with autocratic rulers are diverted to personal offshore accounts.

Third, the Locational Banking Statistics are employed by Henry (2012) to estimate the total value of offshore wealth. The starting point is the global stock of cross-border deposits of around US $\$ 7,000$ trillion in 2010. Based on information from wealth managers that wealthy individuals typically maintain a ratio of liquidity to total assets in the range 3-4.5, the global stock of offshore wealth is estimated at US\$21-32 trillion. This represents an estimate of the foreign household wealth not just by developing countries, but by all countries in the world.

\footnotetext{
${ }^{5}$ The total estimate of illicit capital flows from developing countries is US $\$ 1$ trillion, which consists of US\$200 billion based on the hot-money-narrow method and around US $\$ 800$ billion due to trade misinvoicing; see Section 3.4 and Table 1.
} 


\section{Estimates based on firm behaviour}

\subsection{Profitability and tax incentives for profit shifting}

The most widely used approach for detecting profit shifting is to relate the reported profitability of corporate entities to their production inputs and their tax incentives for profit shifting. To the extent that corporations facing a high tax rate relative to their foreign affiliates systematically report lower profits than corporations with the same production inputs but facing a low tax rate relative to their foreign affiliates, this is taken as evidence on profit shifting.

The method was pioneered by Hines and Rice (1994). This study uses data for foreign affiliates of US multinational enterprises (MNEs) from the Bureau of Economic Analysis aggregated at the country level. It finds robust evidence that US firms report more profits in countries with lower tax rates for a given amount of capital and labour inputs.

The method was first applied to micro-data by Huizinga and Laeven (2008). This study uses accounting data for individual corporations as well as ownership information that links corporations with the same ultimate owner. The data come from the proprietary database Amadeus operated by Bureau van Dijk. It is shown that the profits reported by a corporation are declining in the difference between the statutory tax rate facing the corporation itself and a weighted average of the statutory tax rates facing its foreign affiliates. The paper's key estimate is a semi-elasticity of reported profits or around -1.3 with respect to the tax rate differential.

While Huizinga and Laeven (2008) use a cross-section of corporations, many recent studies extend the method to panels of corporations where profit shifting is identified from the correlation between changes in the tax differential to foreign affiliates and changes in reported profits. The meta-study by Heckemayer and Overesch (2013) finds a consensus semi-elasticity of reported profits with respect to the tax rate differential of around -0.8 .

In recent work, OECD (2015) uses a variant of this method to arrive at an estimated annual global loss of government revenue from base erosion and profit shifting of around US $\$ 100-240$ billion. This is based on an estimated semi-elasticity of reported profits with respect to tax rate differentials of -1.0 as an average across all affiliates of multinational firms and of -1.6 for profitable affiliates: somewhat higher semi-elasticities than the consensus estimates reported by Heckemayer and Overesch (2013). Other important assumptions underlying the estimated revenue loss concern the share of multinational firms in total corporate profits, average tax differentials within multinational firms, and the global corporate tax revenue.

The method has only very recently been applied to developing countries for reasons of data availability. Johannesen et al. (2016) develop methods that are less demanding in terms of data requirements and apply them to a global sample of multinational firms. The paper finds that reported profits are roughly twice as sensitive to tax incentives in developing countries as in developed countries.

Cobham and Janský (2015) use corporate-level data from US multinationals and demonstrate how the profits from their foreign affiliates and their economic activities are not well aligned. They also show how the misalignment is linked with the tax rates in the destination countries, with tax havens capturing a disproportionate share of overall profits. 


\subsection{Transfer prices and tax incentives for profit shifting}

More direct evidence on capital flight through mispricing of transfers within the firm comes from a recent wave of papers that exploit detailed data on international trade to impute transfer prices. Trade data typically include information on values as well as units, which implicitly defines a unit price at the level of the firm, product category, and counterpart country. To the extent that the imputed unit price responds to tax incentives of profit shifting, this represents strong evidence of mispricing.

This method was developed by Bernard et al. (2008) who document that US exporting firms set significantly higher unit prices for the same product when it is sold to third parties than when it is sold to affiliates. Moreover, the difference is increasing in the difference between the US and the foreign corporate tax rate. This is consistent with profit shifting through mispricing of intrafirm exports.

Cristea and Nguyen (2016) use the same technique to impute transfer prices of Danish exporting firms, but make the method more convincing by identifying the effect of taxation from time variation in foreign tax rates and time variation in the group structure. Vicard (2015) is another recent paper that applies the same method to French trade data.

While this methodology is promising in terms of identifying mispricing of intra-firm transfers in a clean and convincing manner, it requires extremely precise and detailed micro-data, which currently makes it difficult to apply in the context of developing countries.

\subsection{Evidence stemming from macro data: corporate income tax base spillovers and returns on foreign direct investment}

Given the limited availability of micro-data for firms and their trade flows in developing countries, there is scope for using macro data to shed light on capital flight through firms.

A recent IMF study by Crivelli et al. (2015) uses country-level data on corporate income tax bases and tax rates to examine how countries' corporate income tax (CIT) tax base is affected, via spillovers, by other countries' tax rates. They distinguish between base spillovers, which may originate from both tax-driven relocation of real economic activities and the reporting of paper profits, and with strategic spillovers, which are due to tax competition (countries reducing their tax rates as a response to competing countries' tax cuts). The emphasis in the paper is on base spillovers.

The authors estimate how a country's CIT base reacts to changes in its own CIT rate and changes in a weighted average of other countries' tax rate. Different weighting schemes are used: countries are weighed either by their economic significance-this scheme emphasizes the reallocation of real economic activities-or using tax haven weights-which only takes into account the tax rates in tax havens. The latter approach serves as an indirect way of measuring profit-shifting activities.

Spillovers are found to be both statistically and economically significant. An interesting finding is that for the non-OECD countries, it is the profit-shifting effect (identified from using tax haven weights) that dominates. Overall, the revenue impacts are large, and these are relatively greater for the developing countries. Their tax revenue losses amount to approximately 1.3 per cent of their GDP. 
UNCTAD (2015) computes the average rate of return on FDI for each developing country and documents that it exhibits a significant correlation with the share of foreign investment deriving from offshore financial centres: when a larger share of FDI is owned by corporations in offshore jurisdictions, the average return is significantly lower. Specifically, increasing the share of FDI originating from offshore jurisdictions by 10 percentage points is found to reduce the rate of return by an estimated 1-1.5 percentage points. Given that corporations in offshore jurisdictions often play no substantial role but merely serve to facilitate profit shifting, this finding is highly suggestive of capital flight from developing countries through firms.

Under certain assumptions, these estimates imply that developing countries annually lose corporate tax base of around US $\$ 450$ billion and tax revenue of around US $\$ 90$ billion. In principle, this computation could be carried out for individual countries rather than for the group of developing countries jointly.

Vicard (2015) takes a slightly different approach and computes the difference between the return on a country's direct investments in other countries and the return on other countries' direct investments in the country itself. It is shown that this 'yield differential' correlates strongly with corporate tax rates for a sample of OECD countries. This is suggestive of tax-motivated capital flight through firms. Again, the yield differential could potentially be computed for individual developing countries and multiplied by total stocks of FDI to obtain country-level estimates of capital flight through firms.

\subsection{Gross excluding reversals method}

This method estimates capital flight through trade mispricing in developing countries by comparing how the same trade flow is valued in the trade statistics of two trading partners of which one is a developed and the other is a developing country. The method has not been used in the academic literature, but is applied routinely by, for instance, Global Financial Integrity in its annual reports on illicit flows of funds (e.g. Global Financial Integrity 2015).

The method proceeds in three steps. First, the trade values reported by the importing country and exporting country are made comparable by stepping up the value of the exporting country by a fixed factor of 10 per cent to account for trade costs. Next, trade mispricing is identified as follows. If the developing country reports a higher (lower) value of imports than the corresponding stepped-up value of exports reported by the developed country, this is considered as over-priced (under-priced) imports into the developing country. If the developing country reports higher (stepped up) exports than the corresponding imports reported by the developed country, this is considered as over-priced (under-priced) exports into the developing country. Finally, all mispricing is summed for each developing country on a gross basis.

The method relies on three strong assumptions. First and most importantly, it assumes that the true trade cost associated with any trade flow is 10 per cent. Any deviation from that figurewhether the true trade costs is higher or lower than 10 per cent-adds to the estimated value of mispriced trade. This is highly problematic because trade prices will naturally vary across products and trading partners. Second, products are not necessarily categorized in the same way in exporting and importing countries, creating discrepancies in product-level analysis (UN Trade Statistics, 2016). Third, it assumes that all mispricing takes place in developing countries whereas all values are truthfully reported in developed countries. This is not obvious since other methodologies have produced abundant evidence of trade mispricing in developed countries too. Fourth, it asserts that all discrepancies in trade statistics are due to mispricing motivated by capital flight whereas, in reality, there could be other reasons, for instance omissions by customs inspectors or errors at the statistical bureaus. 
Nitsch (2016) provides a more detailed review of the methodology used by Global Financial Integrity (2015). He is critical of the use of gross rather than net outflows, as the inflows calculated by the method are greater than the outflows, which would be at odds with the idea that developing countries have suffered from capital flight. He also points out that the results are very sensitive to slight changes in the trade costs assumption and that the estimates fluctuate implausibly from year to year in a country-level analysis.

Application of the method produces very large estimates of trade mispricing. For instance, Global Financial Integrity (2015) reports that the annual illicit flows in and out of developing countries following from mispricing of trade amounts to US\$800 billion. The largest source countries are China, Russia, Mexico, and Malaysia. ${ }^{6}$

\subsection{Abnormal pricing method}

This method uses trade information at the transaction level on value and units to impute the unit price of the traded goods and for each product category a distribution of trade prices is obtained. It is then assumed that abnormal prices are due to mispricing motivated by capital flight.

The method is applied to trade between Russia and the US by Boyrie et al. (2005). They assume that imports into Russia that are priced above the 75 percentile of the price distribution for the relevant product category and exports out of Russia priced below the 25 percentile reflect mispriced trade. The aggregate magnitude of trade mispricing is inferred by summing over all the mispriced transactions. The capital flight component of a mispriced trade transaction is computed as the number of traded units multiplied by the difference between the imputed price and the price quartile. The paper finds that capital flight from Russia to the US in 1999 amounted to roughly US $\$ 5$ billion.

The method is problematic because it ignores that unit prices within a product category vary for a number of natural reasons, for instance differences in objective characteristics or quality. Moreover, the thresholds for normal pricing at 25 per cent and 75 per cent seem highly arbitrary.

\subsection{Event studies}

This method attempts to capture capital flight by measuring the change in firm value occurring around events that change the institutions shaping the opportunities for capital flight.

A recent application is Johannesen and Larsen (2016) who study the adoption of new financial reporting standards by the European Commission. The standards require oil, gas, and mining firms to disclose any tax or other payments made to governments on a country-by-country and project-by-project basis. The explicit goal of the legislation is to counter tax evasion by extractive firms operating in developing countries.

The study reports that the value of extractive firms dropped by around 5 per cent to 10 per cent around the legislative events that led to the adoption of the new reporting rules. This finding suggests that extractive firms derive significant rents from tax evasion and that financial transparency is a powerful tool to curb these rents.

\footnotetext{
${ }^{6}$ Economic Commission for Africa and African Union (2015) also use the method and estimate that capital flows out of Africa amount to US $\$ 50$ billion annually. Recently, UNCTAD (2016) estimated export under-invoicing for selected countries. One of the findings was that many of South African gold exports were apparently unreported. However, this was due to fact that South Africa reported gold exports in a different category, and the analysis that was conducted at product level could not take this into account.
} 


\section{$4 \quad$ Unexplored data sources}

Two recent leaks from offshore banks and service providers represent potentially important data sources on capital flight, but have still been very little used in the academic literature.

First, the leaked files from two large offshore service providers, Portcullis TrustNet and Commonwealth Trust Limited, were published by the International Consortium of Investigative Journalists (ICIJ) in 2013. The leaked files provide information about the names, date of incorporation, and country of residence of shell corporations as well as, in many cases, the country of residence of the ultimate owner. The files have been used by a single paper studying taxpayer responses to the European Savings Directive (Galizia and Galizia 2016), but could potentially also serve to shed light on the timing and magnitude of capital flight through offshore shell companies.

Second, a significant amount of client information from the Swiss subsidiary HSBC Private Bank of the global bank HSBC was leaked in 2008. The ICIJ trawled the files and published the results of their investigation in 2015. The leak covers more than 100,000 accounts with a combined value of more than US $\$ 250$ billion in 2006 and country distributions of accounts and values are now publicly available at the ICIJ website. Given the sheer size of the leak and the plausible assumption that the customers of HSBC were representative of the owners of offshore accounts more generally, the leaks might prove informative in gauging the extent to which different countries suffer from capital flight.

\section{Comparison of estimates from different methods}

The comparison of different kinds of estimates for capital flight is complicated by the fact that some estimates refer to stocks of wealth whereas others refer to annual flows. Another complication is that some estimates are global whereas others point to regional figures. Nonetheless, we have attempted to collect different estimates in Table 1.

\footnotetext{
${ }^{7}$ http://projects.icij.org/swiss-leaks/.
} 
Table 1: Some key estimates of capital flight

\begin{tabular}{|c|c|c|c|}
\hline Concept & Reference & Method & Estimate \\
\hline \multicolumn{4}{|c|}{ Hidden wealth } \\
\hline & Henry (2012) & $\begin{array}{l}\text { Sources-and-uses + } \\
\text { conversion to stock }\end{array}$ & US\$21-32 trillion \\
\hline & Zucman (2015) & $\begin{array}{l}\text { Assets and liabilities } \\
\text { disparities }\end{array}$ & US $\$ 8$ trillion \\
\hline \multicolumn{4}{|c|}{$\begin{array}{l}\text { Flows based on macro- } \\
\text { approaches }\end{array}$} \\
\hline & UNDP (2011) & Sources-and-uses & $\begin{array}{l}\text { US } \$ 20 \text { billion from the } \\
\text { least developed } \\
\text { countries }\end{array}$ \\
\hline & Henry (2012) & Sources-and-uses & $\begin{array}{l}\text { US } \$ 150-200 \text { billion } \\
\text { from all developing } \\
\text { countries }\end{array}$ \\
\hline Profit ohi & $\begin{array}{l}\text { Global Financial Integrity } \\
(2015)\end{array}$ & $\begin{array}{l}\text { Hot money narrow }+ \text { trade } \\
\text { misinvoicing }\end{array}$ & $\begin{array}{l}\text { US\$1 trillion from } \\
\text { developing countries }\end{array}$ \\
\hline & OECD (2015) & $\begin{array}{l}\text { Relation of MNE profits to } \\
\text { tax differentials }\end{array}$ & $\begin{array}{l}\text { US } \$ 100-240 \text { billion } \\
\text { globally }\end{array}$ \\
\hline & Crivelli et al. (2015) & $\begin{array}{l}\text { Macro data, relation with } \\
\text { CIT base and rates }\end{array}$ & $\begin{array}{l}\text { Revenue loss US } \$ 200 \\
\text { billion to non-OECD } \\
\text { countries }\end{array}$ \\
\hline & UNCTAD (2015) & Return to FDI & $\begin{array}{l}\text { Revenue loss of } \\
\text { US } \$ 90 \text { billion to } \\
\text { developing countries }\end{array}$ \\
\hline
\end{tabular}

Source: Authors' illustration.

Consider first the stock of global hidden wealth. As we discussed above, Zucman (2015) estimates hidden wealth to equal US\$7.6 trillion whereas Henry's (2012) estimate is US\$21-32 trillion, at least three times higher. One problematic issue in Henry's estimate is that it also includes money that belongs to corporations which is invested abroad not necessarily for tax evasion purposes but rather to diversify portfolios. On the other hand, Zucman's estimates do not include non-financial wealth nor certain life-insurance strategies. For these reasons, Zucman regards his estimate as a likely minimum, but he also views Henry's estimates as excessive and sees a wealth of around US $\$ 10$ trillion as a plausible ballpark.

The differences between flow estimates based on balance-of-payment methods (e.g. hot money narrow) from developing countries are consistent within themselves. They range from around US $\$ 200$ billion annually (Global Financial Integrity 2015) to US $\$ 20$ billion (UNDP 2011, for the least developed countries) and to US\$150-200 billion (Henry 2012).

While conceptually different, it is also useful to contrast these to the sum of annual capital income earned by residents in Asia, Latin America, and Africa on their hidden wealth, using Zucman's stock estimate and a 5 per cent return. This amounts sums up to US\$125 billion.

For Africa, Zucman estimates that the loss in tax revenue due to capital flight by individuals was US $\$ 14$ billion in 2014. In the same year, the African countries received US $\$ 54$ billion in terms of official development assistance (ODA) (OECD 2016), and their overall tax revenue was around US\$350 billion (own calculations, based on ICTD GRD, see Prichard et al. 2014). 
Crivelli et al. (2015) estimate that the long-run loss of tax revenue due to tax avoidance by firms amounts to approximately 1.3 per cent of GDP for non-OECD countries. In 2014, the GDP for Sub-Saharan African countries was around US $\$ 1,600$ billion, ${ }^{8}$ meaning that a 1.3 per cent reduction in terms of tax revenues would amount to around US $\$ 20$ billion annually. In total, therefore, the tax revenue loss to African countries due to capital flight would be less than the amount they receive in terms of ODA.

Sub-Saharan African (SSA) countries have raised around 12 per cent of their GDP in tax revenue (Prichard et al. 2014). Given the low overall revenues, the relative importance (around 10 per cent) of the revenue loss is quite large, but correcting international tax avoidance alone will not solve African fiscal challenges. The revenue loss due to international tax avoidance is also smaller than the remittances and net FDI inflows to SSA, which stood at around US\$35 and US $\$ 44$ billion, respectively (World Bank 2016a, 2016b).

This estimate does not take directly into account capital loss due to trade mispricing, unlike Global Financial Integrity (2015). The reason for this is that the part of it which is driven by the desire to avoid corporate taxation should already be incorporated in the corporate income tax base effect of Crivelli et al. (2015). ${ }^{9}$ What remains omitted in our approach is potential tax fraud related to trade duties. One needs to remember, however, that several caveats are associated with the method used to estimate trade mispricing.

This conclusion differs from some earlier ones-claiming that the opposite were true-for two reasons. First, we use more recent (and arguably more credible) estimates of the extent of capital flight. Second, we do not contrast the capital flight itself to ODA; rather, we compare the extent of lost tax revenues due to capital flight with ODA. We see the latter comparison as a more meaningful one, since the tax rate on capital income, were it reported, would not be 100 per cent. $^{10}$

\section{Conclusion}

The discussion above can be summarized as follows:

- Measurement of capital flight is inherently difficult because of the nature of the issue.

- Still, recent years have seen progress in methodologies and the more recent estimates are arguably more reliable than earlier ones.

- In terms of the stock estimate, the largest estimates are not plausible, but the stock of hidden wealth is still considerable worldwide.

- The hidden wealth appears to be a proportionally larger worry to some developing countries.

\footnotetext{
${ }^{8}$ See http://data.worldbank.org/region/SSA.

${ }^{9}$ The reason is that if a firm cheats by under-pricing its exports or over-pricing its imports, its profits will decrease.

${ }^{10}$ According to Global Financial Integrity (2015), illicit capital flight from Africa in 2013 was US $\$ 75$ billion, which is more than the ODA flows. Even if this figure were right, all of it would not necessarily be gathered as tax revenues.
} 
- For firms there is ample evidence that profit shifting occurs via transfer pricing for developed countries.

- Until very recently there was no solid evidence regarding profit shifting by firms for developing countries. However, recent studies show that the problem is present for them as well and the worry that the problem is more severe for developing than developed countries is also supported empirically.

- The fact that developing countries are relatively more dependent on corporate income tax revenue reinforces the considerable negative impact of profit shifting for them by multinational companies.

While the purpose of this study is not to review the effectiveness of the means targeted to combat tax evasion, we would still like to point out the following:

- While international tax evasion is a serious problem and should not be underestimated, developing countries also need to improve their domestic tax capacity (which includes the performance of consumption taxation and income taxation), as the domestic tax instruments will always be responsible for raising the bulk of the tax revenue.

- There has been progress in information exchange between countries that is needed to fight evasion by individuals. Developing countries' opportunities to benefit from these is likely to be hampered by limited administrative resources. One potentially useful aid intervention is technical assistance for these and other tax matters.

- The OECD BEPS initiative that is meant to address problems in tax evasion by firms faces many challenges, especially again for developing countries. Some economists see the current system as fundamentally flawed (Devereux 2015) because of the extremely hard-to-solve problems of asymmetric information between companies and tax authorities and suggest radically different alternatives. The promise of these alternative systems for developing countries is a completely unexplored issue.

- Illicit capital flights from developing countries are often compared with the money channelled to them as official development assistance. However, the comparison, while illustrative, is not necessarily that meaningful as part of the illicit flows is arguably related to difficult economic and political conditions in the developing countries. This, on the other hand, is one problem that development assistance is trying to solve. If the comparison is, nonetheless, carried out for African countries, it appears that African countries receive more ODA than they lose from tax revenues due to capital flight.

- One policy conclusion that the recent estimates give rise to is that they reinforce the point to target aid efforts to fostering tax capacity in developing countries. More evidence on the effectiveness of exactly how technical assistance in the field of taxation should be designed would be extremely useful. 


\section{References}

Andersen, J., N. Johannesen, D. Lassen, and E. Paltseva (2016). 'Petro Rents, Political Institutions, and Hidden Wealth: Evidence from Offshore Bank Accounts'. Journal of the European Economic Association, forthcoming.

Bernard, A., J. Jensen, and P. Schott (2006). 'Transfer Pricing by U.S.-based multinationals. NBER Working Paper 12493. Cambridge, MA: National Bureau of Economic Research.

Boyce, J. (1992). 'The Revolving Door? External Debt and Capital Flight: A Philippine Case Study'. World Development, 20(3): 335-49.

Boyrie, M., S. Pak, and J. Zdanowicz (2005). 'Estimating the Magnitude of Capital Flight due to Abnormal Pricing in International Trade: The Russia-USA Case'. Accounting Forum, 29: 249_ 70.

Claessens, S., and D. Naudé (1993). 'Recent Estimates of Capital Flight'. Policy Research Working Paper 1186. Washington, DC: World Bank.

Cobham, A., and P. Janský (2015). 'Measuring Misalignment: The Location of US Multinationals' Economic Activity Versus the Location of their Profits'. ICTD Working Paper 42. Brighton: International Centre for Tax and Development.

Cristea, A., and D. Nguyen (2016). 'Transfer Pricing by Multinational Firms: New Evidence from Foreign Firm Ownerships'. American Economic Journal: Economic Policy, forthcoming.

Crivelli, E., R. de Mooij, and M. Keen (2015). 'Base Erosion, Profit Shifting and Developing Countries'. IMF Working Paper 15/118. Washington, DC: International Monetary Fund.

Davies, J.B., S. Sandström, A. Shorrocks, and E.N. Wolff (2011). 'The Level and Distribution of Global Household Wealth'. Economic Journal, 121(551): 223-54.

Devereux, M. (2015). 'Is a Sustainable Tax on International Profit Feasible?'. Keynote address at International Institute of Public Finance Conference, Dublin, 20-23 August.

Economic Commission for Africa and African Union (2015). 'Illicit Financial Flow'. Report of the High Level Panel on Illicit Financial Flows from Africa. Addis Ababa: United Nations Economic Commission for Africa and African Union.

Forstater, M. (2015). 'Can Stopping “Tax Dodging” by Multinational Enterprises Close the Gap in Development Finance?’. CGD Policy Paper 069. Washington, DC: Center for Global Development.

Galizia, M., and P. Galizia (2016). 'Offshore Financial Activity and Tax Policy: Evidence from a Leaked Dataset'. Journal of Public Policy, forthcoming.

Global Financial Integrity (2015). 'Illicit Financial Flows from Developing Countries: 20042013'. Washington, DC: Global Financial Integrity.

Heckemayer, J.H., and M. Overesch (2013). 'Multinationals' Profit Response to Tax Differentials: Effect Size and Shifting Channels'. ZEW Working Paper 13-045. Mannheim: Center for European Economic Research.

Henry, J. (2012). The Price of Offshore Revisited. Chesham, Bucks: Tax Justice Network.

Hines J., and E. Rice (1994). 'Foreign Tax Havens and American Business'. Quarterly Journal of Economics, 109(1): 149-82.

Huizinga H., and L. Laeven (2008). 'International Profit Shifting within Multinationals: A MultiCountry Perspective'. Journal of Public Economics, 92: 1164-82. 
Johannesen, N., T. Tørsløv, and L. Wier (2016). 'Are Less Developed Countries more Exposed to Multinational Tax Avoidance?: Method and Evidence from Micro-Data'. WIDER Working Paper 2016/10. Helsinki: UNU-WIDER.

Johannesen, N., and D. Larsen (2016). 'The Power of Financial Transparency: An Event Study of Country-by-Country Reporting Standards'. Economics Letters, forthcoming.

Johannesen, N., and G. Zucman (2014). 'The End of Bank Secrecy? An Evaluation of the G20 Tax Haven Crackdown'. American Economic Journal: Economic Policy, 6(1): 65-91.

Lane, P.R., and G.M. Milesi-Ferretti (2007). 'The External Wealth of Nations Mark II: Revised and Extended Estimates of Foreign Assets and Liabilities, 1970-2004'. Journal of International Economics, 73(2): 223-50.

Lensink, R., N. Hermes, and V. Murinde (2000). 'Capital Flight and Political Risk'. Journal of International Money and Finance, 19(1): 73-92.

Ndikumana, L., J. Boyce, and A. Ndiaye (2014). 'Capital Flight: Measurement and Drivers'. In S.I. Ajayi and L. Ndikumana (eds), Capital Flight from Africa: Causes, Effects and Policy Issues. Oxford: Oxford University Press.

Nitsch, V. (2016). 'Trillion Dollar Estimate: Illicit Financial Flows from Developing Countries'. Darmstadt Discussion Papers in Economics 227. Darmstadt: Technische Universität Darmstadt.

OECD (2015). 'Measuring and Monitoring BEPS, Action 11-2015 Final Report'. OECD/G20 Base Erosion and Profit Shifting Project. Paris: OECD.

OECD (2016). 'Development Aid at a Glance: Statistics by Region'. 2. Africa, 2016 Edition. Available at: http://www.oecd.org/dac/stats/documentupload/2\%20Africa\%20\%20Development $\% 20$ Aid $\% 20$ at $\% 20 a \% 20$ Glance $\% 202016$.pdf (accessed 15 August 2016).

Pastor, M. (1990). 'Capital Flight from Latin America'. World Development, 18(1): 1-18.

Prichard, W., A.F. Cobham, and A. Goodall (2014). 'The ICTD Government Revenue Dataset'. ICTD Working Paper 19. Brighton: International Centre for Taxation and Development.

Schjelderup, G. (2016). 'Secrecy Jurisdictions'. International Tax and Public Finance, 23(1): 168-89.

UNCTAD (United Nations Conference on Trade and Development) (2015). 'World Investment Report: Reforming International Investment Governance'. Geneva: UNCTAD.

UNCTAD (United Nations Conference on Trade and Development) (2016). 'Trade Misinvoicing in Primary Commodities in Developing Countries: The Cases of Chile, Côte d'Ivoire, Nigeria, South Africa and Zambia'. New York and Geneva: UNCTAD.

UNDP (United Nations Development Programme) (2011). 'Illicit Financial Flows from the Least Developed Countries: 1990-2008'. Discussion Paper. New York, NY: UNDP.

UN Trade Statistics (2016). Available at: http://unstats.un.org/unsd/tradekb/Knowledgebase/50657/Bilateral-asymmetries (accessed 22 August 2016.)

Vicard, V. (2015). 'Profit Shifting through Transfer Pricing: Evidence from French Firm Level Trade Data'. Banque de France Working Paper 555. Paris: Banque de France.

World Bank (2016a). 'Migration and Remittances Recent Developments and Outlook'. Migration and Development Brief 26. Washington, DC: World Bank.

World Bank (2016b). World Development Indicators. Available at: http://data.worldbank.org/data-catalog/world-development-indicators. 
Zucman, G. (2013). 'The Missing Wealth of Nations, Are Europe and the U.S. Net Debtors or Net Creditors?'. Quarterly Journal of Economics, 128(3): 1321-364.

Zucman, G. (2015). The Hidden Wealth of Nations. The Scourge of Tax Havens. Chicago, IL: The University of Chicago Press. 